\title{
IN VITRO AND IN VIVO ANTIFUNGAL ACTIVITY OF ALKALOID 3,5-bis(4,4"'-dimethoxy- [1,1':2',1'-terphenyl]-4'-yl)-4H-pyrazole-4,4-diol FROM DERRIS INDICA (LAM) BENNETT SEEDS
}

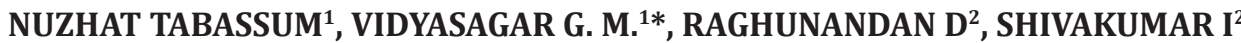 \\ ${ }^{1}$ Department of Post-Graduate Studies and Research in Botany, Medicinal Plants and Microbiology Research Laboratory, Gulbarga \\ University, Kalaburagi, Karnataka, India. ${ }^{2}$ Department of Pharmaceutical and Nano Chemistry, Matoshree Taradevi Rampure Institute of \\ Pharmaceutical Sciences, Kalaburagi, Karnataka, India. Email: gmvidyasagar@rediffmail.com
}

Received: 10 March 2021, Revised and Accepted: 10 May 2021

\section{ABSTRACT}

Objectives: The aim of the present study is to isolate an antifungal compound from Derris indica (Lam) Bennett seed oil with various solvents and evaluation of its antifungal activity against the clinical species of Candida.

Methods: D. indica seed hexane extract was tested against Trichophyton rubrum, Trichophyton tonsurans and Candida albicans. Hexane extract was fractioned using different solvents through column chromatography (CC). Isolated compound D1 was identified and characterized using ultraviolet, Fourier-transform infrared, ${ }^{1} \mathrm{HNMR}$, and mass spectroscopy. In vitro evaluation of D1 carried out against 12 Candida strains. In vivo evaluation of D1 carried out against T. rubrum, T. tonsurans, and C. albicans using an excision wound healing model on male Wistar rats.

Results: Different concentrations of hexane extract showed antimicrobial activity against tested microorganism with varying minimum inhibitory concentration values. On fractionation with hexane-petroleum ether through CC, it yielded a crystalline fraction. Compound D1 characterized as a 3,5-bis (4,4"-dimethoxy-[1,1': 2',1"-terphenyl]-4'-yl)-4H-pyrazole-4,4-diol. A novel alkaloid compound from $D$. indica is a new report and proved

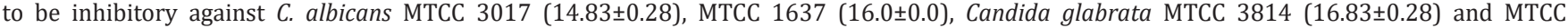

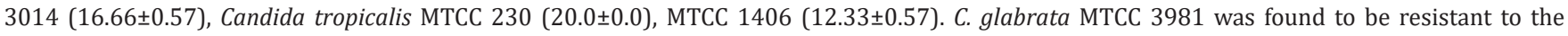
compound. In vivo studies showed no visual symptoms at the end of treatment indicating the therapeutic property of the compound.

Conclusion: The D1 was found to be effective against human fungal pathogens and can be used as a base molecule in designing new antifungal drugs.

Keywords: Derris indica, Seed oil, Alkaloid compound, In vitro, In vivo studies.

(c) 2021 The Authors. Published by Innovare Academic Sciences Pvt Ltd. This is an open access article under the CC BY license (http://creativecommons.org/ licenses/by/4.0/) DOI: http://dx.doi.org/10.22159/ajpcr.2021v14i6.41383. Journal homepage: https://innovareacademics.in/journals/index.php/ajpcr

\section{INTRODUCTION}

Derris indica belonging to the family Fabaceae (Papilionaceae) is a medium-sized evergreen, fast-growing, glabrous, and deciduous tree widely distributed in the region of Southeast Asia and Pacific Islands [1]. It is one of the nitrogen fixing tree producing seeds containing $30-40 \%$ oil [2]. This versatile medicinal plant is the unique source of various types of chemical compounds [3]. The plant is reported to produce a wide range of flavonoids with antimicrobial activity [4-16]. The seeds contain $13.5 \%$ mucilage, traces of essential oil and complex amino acids, termed glabrin. Four furanoflavones karanjin, pongapin $\left(\mathrm{C}_{19} \mathrm{H}_{12} \mathrm{O}_{6}\right)$, kanjone $\left(\mathrm{C}_{18} \mathrm{H}_{12} \mathrm{O}_{4}\right)$, and pongaglabrone $\left(\mathrm{C}_{18} \mathrm{H}_{10} \mathrm{O}_{5}\right)$, have been isolated from Indian Karanja seed [17]. Three furanoflavonoids (Pongamosides $\mathrm{A}, \mathrm{B}$, and $\mathrm{C}$ ) and a flavonol, glucoside, and pongamoside $\mathrm{D}$ have been reported from n-butanol-soluble fraction of ethanolic extract of $D$. indica fruit [7]. Pongaglabol, hydroxyfuranoflavone, aurantiamide acetate, four furanoflavones (karanjin, lancheolatin B, kanjone, and pinnatin) and a rarely occurring modified phenylalanine dipeptide have been isolated [18]. Conventionally, the plant has been used in the treatment of several ailments. The bark is used in pile, leave in medicated bath and rheumatic pains, seeds in hypertension, bronchitis, whooping cough, skin diseases and rheumatic arthritis, roots in cleaning gums, teeth, ulcers and gonorrhea, and flowers are used in the treatment of diabetes[19].

Nowadays, antibiotics have created an enormous clinical problem in the treatment of infectious diseases [20]. Skin fungal infections are predictably grouped into superficial, subcutaneous and systemic infections [21]. According to the World Health Organization survey on the incidence of dermatophytic infection, about $20 \%$ worldwide populations have suffered with cutaneous infections [22]. Unlike other fungi, dermatophytes are communicable and cause infections in healthy, immune-competent individuals as well as in those with immune dysfunction [23]. Herbal drugs have great need and play a key role in health-care systems [24]. Therapeutic property of herbal drugs is due to the presence of active constituents such as alkaloids, glycosides, saponins, terpenoids, lactones, phenols, and flavonoids present in different parts of plants $[25,26]$. D. indica is a unique source of various phytoconstituents belonging to alkaloids, glycosides, flavonoids, fixed oils, and carbohydrate responsible for various activities [27]. Previously, numerous authors reported the presence of various phytocompounds in seeds [28-31]. These compounds have many interesting pharmacological and industrial applications. The aim of the present study is to isolate an antifungal compound from D. indica seeds

\section{METHODS}

\section{Collection of plant materia}

D. indica mature seeds collected from Gulbarga University campus and local areas of Kalaburagi district, Karnataka, India, and authentically identified using herbarium deposited in the Department of Botany, Gulbarga University, Kalaburagi, Karnataka, India, with voucher specimen number HGUG-206 and literatures [32-34].

\section{Preparation of extract}

Seeds were washed with water, dried for 4-5 days at room temperature and pulverized to fine powder (particle size $2 \mathrm{~mm}$ ) and extracted 
with Soxhlet extractor $\left(40^{\circ} \mathrm{C}\right)$ with hexane for $12 \mathrm{~h}$. The extracted oil obtained was condensed and filtered using Whatman No. 1 filter paper, evaporated in vacuo, percent of the extract was recorded and stored in an airtight screw-capped bottle and stored at $4^{\circ} \mathrm{C}$ in the refrigerator for further use.

\section{Fractionation and identification}

Hexane extract $(10 \mathrm{mg}$ ) was dissolved in $100 \mathrm{ml}$ of hexane and used as a test solution. It was subjected to standard methods of phytochemical analysis to detect the presence of phytoconstituents [35-38] and also physicochemical analysis, namely, color, boiling point, solubility, estimation, iodine value, acid value, and saponification value. The column chromatography (CC) over silica gel-H of mesh size 60-120 $\mu$ (HiMedia, Mumbai) using eluent mixtures of hexane, pet ether, chloroform, ethyl acetate, and methanol (Sd-fine, Mumbai) of increasing polarity at a flow rate of $1 \mathrm{ml} / \mathrm{min}$ was employed. Each $5 \mathrm{ml}$ of 16 fractions were collected into a plate. Active fraction from antifungal assay, fraction-1 using solvent system hexane-petroleum ether $(6: 4, \mathrm{v} / \mathrm{v})$ was checked by the thin-layer chromatography (TLC) coated silica gel- $G$, to know the purity of fractions. TLC plates were prepared as formulated [39] TLC plates were visualized by spraying $\mathrm{H}_{2} \mathrm{SO}_{4}(50 \%)$, heating for 8-10 min at $80^{\circ} \mathrm{C}$.

Fraction 1 was purified by recrystallization to give pure compound. The melting point was determined by Thiele tube melting point apparatus. The obtained pure compound was subjected to liquid chromatographymass spectrometry (LC-MS) analysis to determine the corresponding molecular ions present in the compound and analyzed in a Shimadzu LC-MS model 2010 A, in JEOl Model GS×400 spectrophotometer with $\mathrm{CDCL}_{3}$ (denaturated chloroform, DMSO) as the solvent. An ultraviolet (UV)/visible spectrum was obtained using a 5704SS ELICO spectrophotometer in the range of 200-800 nm wavelengths. Fouriertransform infrared (FTIR) spectrum was measured using $\mathrm{KBr}$ discs on Perkin-Elmer $\mathrm{R} \times 1$ spectrophotometer in the wave numbers $\left(\mathrm{cm}^{-1}\right)$ in the range of $4000-450 \mathrm{~cm}^{-1}$. NMR was performed to determine the structure of an isolated pure compound. ${ }^{1} \mathrm{HNMR}$ was recorded using Bruker AM $\times 400$ NMR spectrometer using TMS (Tetramethyl saline) as an internal reference at $400.137 \mathrm{MHz}$ in $\mathrm{CDCL}_{3}$ at $300 \mathrm{~K}$. The chemical shifts were recorded in $\sigma(\mathrm{ppm})$ and $\mathrm{J}$ in hertz and compared with literature data.

\section{Biological assay \\ Test organisms}

Trichophyton rubrum and Trichophyton tonsurans were collected from Mahadevappa Rampure Medical College, Kalaburagi and 12 Candida species, namely, Candida albicans MTCC 183, MTCC 3017, and MTCC 1637, Candida glabrata MTCC 3814, MTCC 3014, and MTCC 3981, Candida haemulonii MTCC 1966, MTCC 2766, and MTCC 8303, and Candida tropicalis MTCC 230, MTCC 1406, and MTCC 2795 were obtained from Institute of Microbial Technology, Chandigarh, India. The fungal cultures were maintained on Sabouraud Dextrose Agar (SDA) medium supplemented with Chloramphenicol and Streptomycin sulfate and subcultured on Potato Dextrose Agar every 15 days to prevent pleomorphic transformations. Yeast peptone dextrose (YPD) agar media were used for the assay.

\section{Drug preparation}

The isolated compound D1 diluted in 1\% (v/v) Dimethyl formamide (DMF) at a concentration of $5 \mathrm{mg} / \mathrm{ml}$. Stock solution of the drug powder, Ketoconazole was prepared in $1 \%(\mathrm{v} / \mathrm{v}) \mathrm{DMF}$ at a concentration of $1 \mathrm{mg} / \mathrm{ml}$ and stored at $-20^{\circ} \mathrm{C}$ and used for the assay.

\section{Agar well diffusion assay}

Antifungal activity of the $D$. indica hexane extract was evaluated against T. rubrum and $C$. albicans. The fungal cell suspensions were prepared according to the following procedure. Fungal lawn was prepared using 5 days old culture strain. The fungal strains were suspended in a saline solution $(0.85 \% \mathrm{NaCl})$ and adjusted to a turbidity of 0.5 MacFarland standards (108 CFU/ml) and used for the assay. The determination of minimum inhibitory concentration (MIC) of extract was performed by serial dilution $(0.6,1.2,2.5,5,10,20$, and $40 \mathrm{mg} / \mathrm{ml})$ in DMF (v/v) against tested organisms by agar well diffusion method [40]. The petri dishes were prepared in triplicates and maintained at $37^{\circ} \mathrm{C}$ for $48 \mathrm{~h}$. The diameter of zones of inhibition was measured in $\mathrm{mm}$ and statistically analyzed and expressed as mean $(n=3) \pm$ standard deviation (SD). DMF used as negative control and Ketoconazole $(1000 \mu \mathrm{g} / \mathrm{ml})$ as positive control. Similarly in vitro antifungal testing of isolated compound D1 was carried out against Candida species by above mentioned method on YPD agar plates.

\section{Excision wound healing from isolated compound D1 Animals}

Wistar male rats weighing about $250 \mathrm{~g}$ were used for wound healing study. Animals were maintained in propylene cages at room temperature $22 \pm 2^{\circ} \mathrm{C}$; relative humidity $\sim 60 \%$ in a 12 -h light-dark cycle. Rats were given pelleted diet and tap water ad libitum. Animal experiment procedures were carried out in accordance with the guidelines of the Public Health Service Policy on Human Care and use of laboratory animals (Matoshree Taradevi Rampure Institute of Pharmaceutical Sciences, Kalaburagi) and the protocol was approved by the institutional animal ethical committee (HKE/COP/IAEC/66/2013) for care and use.

\section{Analysis of non-harmful effects}

To determine the non-harmful effect of the effective compound, male Wistar rats (250 g) were used and maintained under the same condition as described above. Wistar rats were randomly divided into five groups and each group containing five rats. According to concentration of applied compound investigated. The compound considered as nonharmful if all the five animals in a group survive after $48 \mathrm{~h}$ application. About $0.5 \mathrm{ml}$ of prepared stock solution of the effective compound was diluted in ethanol $(0.01,0.1,0.2,0.3$, and $0.4 \%$, vol/vol) and injected intraperitoneally. About $0.1 \%$ concentration was non-harmful to the animals and selected to use for further investigation.

\section{Wound healing activity}

Excision wound was used to evaluate the wound healing activity of compound D1. The rats were inflicted excision wound as described $[41,42]$. The groups were divided as; $1^{\text {st }}$ group-untreated animals served as a control, $2^{\text {nd }}$ group-animals treated with standard, $3^{\text {rd }}$ grouptreated with compound against $\mathrm{T}$. rubrum, $4^{\text {th }}$ group-treated with compound against $\mathrm{T}$. tonsurans, and $5^{\text {th }}$ group treated with compound against $C$. albicans. $4 \mathrm{~cm}^{2}$ areas were cleaned and depilated on the back of each animal. The inoculum was applied on the back of the animals immediately after depilation and left for 3 days. The establishment of active infection was confirmed on day 4 by isolation of the pathogens from skin scales cultured and by visual examination on 8-10 days. The treatment was initiated on animals with active infections, from the $20^{\text {th }}$ day post-inoculation and continued till complete recovery from infection was achieved. Treatment started, and ointment contained $0.1 \%$ (vol/vol) of compound, separately mixed in petroleum jelly, applied once daily on infected area and scored visually for inflammation and scaling. The commercial fungicide ketoconazole used as a control. Clinical assessment of inoculated skin area was performed using a modified lesion score from 0 to 4 as indicated. The recorded score 0 indicates no visible lesion; score 1 few slightly erythematous lesions; score 2 well-defined vesicles; score 3 large areas of marked redness, scaling, blade patches; and score 4 mycotic foci well developed with ulceration. The lesion was scored from 1, 3, 10, 20, 30, and 40 days. The presence of the pathogens was confirmed by cultivation of skin scales from infected loci on SDA plates each day.

\section{RESULTS AND DISCUSSION}

\section{Agar well diffusion assay}

D. indica seed hexane extract was first subjected to agar well diffusion assay to identify the presence of potential antifungal compounds. The 
Table 1: MIC of $D$. indica seed extract

\begin{tabular}{|c|c|c|c|c|c|c|c|c|c|c|}
\hline \multirow[t]{2}{*}{ S. No. } & \multirow{2}{*}{$\begin{array}{l}\text { Botanical } \\
\text { name and } \\
\text { part used }\end{array}$} & \multirow[t]{2}{*}{ Family } & \multicolumn{8}{|c|}{ Zone of inhibition } \\
\hline & & & $\begin{array}{l}\text { Test } \\
\text { organism }\end{array}$ & $40 \mathrm{mg} / \mathrm{ml}$ & $20 \mathrm{mg} / \mathrm{ml}$ & $10 \mathrm{mg} / \mathrm{ml}$ & $5 \mathrm{mg} / \mathrm{ml}$ & $2.5 \mathrm{mg} / \mathrm{ml}$ & $1.25 \mathrm{mg} / \mathrm{ml}$ & $0.62 \mathrm{mg} / \mathrm{ml}$ \\
\hline 1. & $\begin{array}{l}\text { Derris indica } \\
\text { (Seeds extract) }\end{array}$ & Fabaceae & $\begin{array}{l}\text { C. albicans } \\
\text { T. rubrum }\end{array}$ & $\begin{array}{l}18.83 \pm 0.28 \\
16.83 \pm 0.28\end{array}$ & $\begin{array}{l}16.83 \pm 0.28 \\
14.16 \pm 0.28\end{array}$ & $\begin{array}{l}13.5 \pm 0.5 \\
13.83 \pm 0.28\end{array}$ & $\begin{array}{l}12.83 \pm 0.28 \\
12.0 \pm 0.0\end{array}$ & $\begin{array}{l}11.16 \pm 0.28 \\
10.66 \pm 0.28\end{array}$ & $\begin{array}{l}10.83 \pm 0.28 \\
9.66 \pm 0.28\end{array}$ & $\begin{array}{l}12.0 \pm 0.0 \\
7.16 \pm 0.28\end{array}$ \\
\hline 2. & Positive control & & Ketaconazole & $24.0 \pm 0.0$ & & & & & & \\
\hline 3. & Negative control & & DMF & NA & & & & & & \\
\hline
\end{tabular}

inhibitory activity on tested fungi was quantified by the diameter of zones of inhibition. MIC extract at different concentration showed antifungal activity $(0.62-40 \mathrm{mg} / \mathrm{ml})$ against pathogenic fungi $C$. albicans and T. rubrum with varying MIC values and summarized (Table 1). Among all the concentrations maximum zones of inhibition showed $18.83 \pm 0.28$ (C. albicans) and $16.83 \pm 0.28$ (T. rubrum) at $40 \mathrm{mg} / \mathrm{ml}$ and found to be more effective concentration. Several researchers reported that alkaloids, phenols, triterpenoids, glycosides, and tannins have high potential that could be developed as antimicrobial compounds [43,44]. The result observed in the present study suggests that the hexane extract inhibit the growth of microbes by the presence of these phytochemicals which are responsible to inhibit the fungal metabolism. A varied level of broad-spectrum antimicrobial activity was observed by authors from various parts of $D$. indica on fractionation with different solvents and suggested the use of fatty oil of $D$. indica plant as antimicrobial drugs against pathogenic bacteria and fungi [45-48].

\section{NA-no activity, DMF-Dimethyl formamide}

Fractionation and identification

Phytochemical screening tests were conducted to determine the presence of various secondary metabolites present in $D$. indica hexane seeds extract. Phytochemical screening results revealed the presence of steroids, glycosides, flavonoids, alkaloids, and saponins in the extracts $[37,38]$.

Plant was collected based on their ethnopharmacological significance and used as traditional medicine by herbal practitioners and local people. Detailed information was gathered by several interviews [49]. In our previous study, phytochemical screening tests were conducted to determine the presence of various secondary metabolites present in D. indica seeds hexane extract and results were compared with reported literature data found to be similar with chloroform extract $[50,51]$. The results of physicochemical characterizations of hexane extract were found to be soluble in hexane, petroleum ether, chloroform, ethyl acetate, methanol, DMF and DMSO whereas insoluble in water. The extract was brown color with a boiling point $\left(210^{\circ} \mathrm{C}\right)$ and the content of hexane extract was weighed (49\%). This value was more or less similar to the previously reported literatures which confirmed that seeds are a rich source of lipids $[52,53]$. The iodine value of the oil indicates that the amount of saturated fatty acid, and iodine value (119.02 mg of $\mathrm{KOH} / \mathrm{g}$ ), acid value (2.0 mg KOH/g), and saponification value $(181.9 \mathrm{mg}$ $\mathrm{KOH} / \mathrm{g}$ ), respectively. It is evident from the results of phytochemical studies that seeds are rich source of flavonoids, alkaloids, glycosides, and steroids of pharmacological importance. Thus, an attempt was made here to isolate some of these phytochemical compounds from the seeds of $D$. indica by CC and purified with the help of TLC.

In the present investigation isolated compound D1 was obtained as pale yellow rod shaped crystals ( $15.5 \mu \mathrm{m}$ length). There are many reports of isolation of compounds from $D$. indica seed oil in crystal form such as Pongamol [30], Pongapin (II) [54], and Pongol [55]. Further, purity of the fraction was checked by TLC using solvent systems [Hexane-petroleum ether $(6: 4, v / v)]$, hRf value (58.28), appeared as a single discrete spot and melting point recorded as $148-150^{\circ} \mathrm{C}$. Further, pure fraction was subjected for detailed spectroscopic studies. The UV spectrum of compound D1 showed UV ${ }^{\lambda}$ nm wavelength 665.0 and absorbance at 0.600 ranges indicates the presence of the chromophoric group with an extended conjugation (Fig. 1). The FTIR spectrum reveals the presence

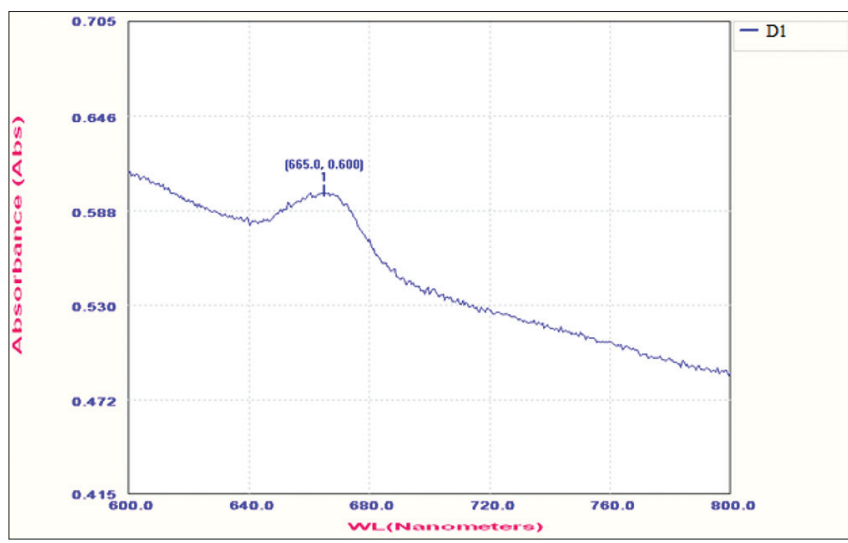

Fig. 1: Ultraviolet spectrum of isolated compound from Derris indica seed oil

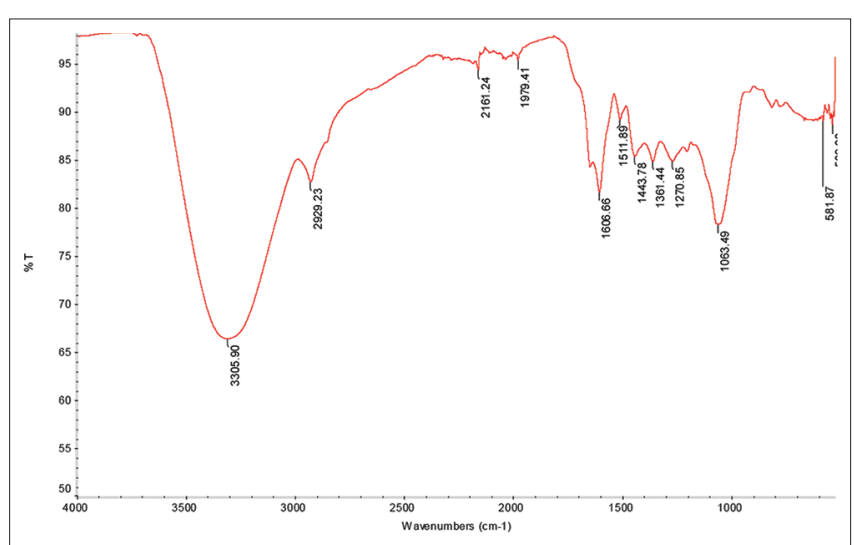

Fig. 2: Fourier-transform infrared spectrum of isolated compound from Derris indica seed oil

of Hydroxyl group (-OH) at $3305 \mathrm{~cm}^{-1}$ broad main absorption band and the additional moderate to intense band $1063^{\mathrm{cm}-1}, 1270^{\mathrm{cm}-1}, 1361^{\mathrm{cm}-1}$, $1443^{\mathrm{cm}-1}$, and $1511^{\mathrm{cm}-1}$ is present in between the ranges $600^{\mathrm{cm}-1}$ and $1600 \mathrm{~cm}-1$. Band $2929 \mathrm{~cm}^{-1}$ is due to stretching $(\mathrm{C}-\mathrm{H})$ and $1606 \mathrm{~cm}^{-1}$ is for $\mathrm{C}=\mathrm{N}$ group stretching (Fig. 2). Its molecular formula was assumed to be $\mathrm{C}_{43} \mathrm{H}_{36} \mathrm{~N}_{2} \mathrm{O}_{6}$ and molecular weight is 676.77 . The mass spectrum indicated the molecular ion peak at $\mathrm{m} / \mathrm{z} 676$ and base ion peak at $\mathrm{m} / \mathrm{z}$ 258 (Figs. 3 and 4).

The ${ }^{1} \mathrm{H}$ NMR spectrum of D1 showed signal at $\delta_{\mathrm{H}} 8.21(1 \mathrm{H}, \mathrm{d}, \mathrm{J}=4 \mathrm{~Hz})$, and $\delta 8.15(\mathrm{dd}), \delta 7.77(\mathrm{~d})$, multiplet between $\delta 7.58-7.54$ and 7.19 (dd) characteristics to aromatic protons. Signals exhibited at $\delta_{H} 3.95(\mathrm{~S})$ correspond to one methoxy proton and $\delta 1.72(\mathrm{~s})$ to hydroxyl protons suggested that compound D1 is alkaloid derivatives. Spectroscopic data support the proposed structure D1 (Fig. 5). The structure of isolated compound was established on the basis of spectroscopic studies. This is the first report that crystalline alkaloid had been found as naturally occurring compound from D. indica seed oil. The physicochemical properties and spectroscopic 
data indicated that compound D1 is an alkaloid and characterized as, 3,5-bis (4,4"'-dimethoxy-[1,1':2',1''-terphenyl]-4'-yl) -4H-pyrazole-

Table 2: In vitro susceptibility assay from compound D1 against Candida species

\begin{tabular}{llllll}
\hline S. No. & Organism & $\begin{array}{l}\text { Strains } \\
\text { of MTCC }\end{array}$ & K & D1 & C \\
\hline 1. & C. albicans & 183 & $23.83 \pm 0.28$ & $12.16 \pm 0.28$ & - \\
& & 1637 & $19.66 \pm 0.28$ & $16.0 \pm 0.0$ & - \\
& & 3017 & $24.0 \pm 0.0$ & $14.83 \pm 0.28$ & - \\
2. & C. glabrata & 3814 & $23.66 \pm 0.28$ & $16.83 \pm 0.28$ & - \\
& & 3014 & $20.0 \pm 0.0$ & $16.66 \pm 0.57$ & - \\
& & 3981 & $11.33 \pm 1.15$ & - & - \\
3. & C. haemulonii & 1966 & $13.83 \pm 0.28$ & $8.16 \pm 0.28$ & - \\
& & 2766 & $16.66 \pm 0.28$ & $8.0 \pm 0.0$ & - \\
4. & & 8303 & $16.66 \pm 0.28$ & $8.33 \pm 0.57$ & - \\
& C. tropicalis & 230 & $24.0 \pm 0.0$ & $20.0 \pm 0.0$ & - \\
& & 1406 & $20.0 \pm 0.0$ & $12.33 \pm 0.57$ & - \\
& & 2795 & $16.83 \pm 0.28$ & $6.33 \pm 0.57$ & - \\
\hline
\end{tabular}

C. albicans: Candida albicans, C. glabrata: Candida glabrata, C. haemulonii: Candida haemulonii, C. tropicalis: Candida tropicalis

Table 3: In vivo studies of isolated compound D1 against pathogenic fungi on male Wistar rats

No. of Group I Group II Group III Group IV T. Group V C. treated control standard Trubrum tonsurans albicans days

\begin{tabular}{llllll}
\hline $1^{\text {st }}$ day & - & - & - & - & - \\
$3^{\text {rd }}$ day & 1 & 1 & 1 & 1 & 1 \\
$5^{\text {th }}$ day & 2 & 1 & 2 & 3 & 2 \\
$10^{\text {th }}$ day & 3 & 0 & 2 & 2 & 2 \\
$20^{\text {th }}$ day & 4 & 0 & 1 & 1 & 1 \\
$30^{\text {th }}$ day & 3 & 0 & 1 & 0 & 0 \\
$40^{\text {th }}$ day & 3 & 0 & 0 & 0 & 0 \\
$45^{\text {th }}$ day & 3 & 0 & 0 & 0 & 0 \\
\hline
\end{tabular}

T. rubrum: Trichophyton rubrum, T. tonsurans: Trichophyton tonsurans, C. albicans: Candida albicans

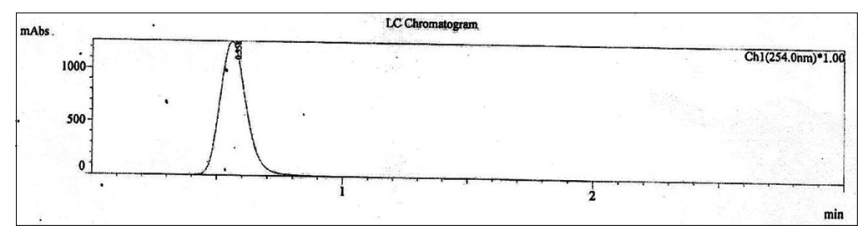

Fig. 3: Liquid chromatographic spectrum of isolated compound from Derris indica seed oil 4,4-diol. According to reports, alkaloids are secondary metabolites originally defined as pharmacologically active compounds, primarily composed of nitrogen [56,57]. Alkaloids are predominant in plant families such as Fabaceae, Asteraceae, Apocynaceae, and Boraginaceae [60].

There are reports on the presence of numerous phytocompounds isolated from D. indica seeds, such as furanoflavones [15,54,55,59], Furanodiketon [60], Karanjachromene [30], isopongachromene [60], isoponga flavone [61], 0-methyl pongaglabol [62], $3,3^{1}, 4^{1}, 7$ - tetramethoxyflavone [60], fatty acids [63], Pongamoside D [7], Glabrachalcone, Karangin, Glabrachalcone [63], and alkaloids [65]. After reviewing literatures, this is the first time report of occurrence of crystalline alkaloid from $D$. indica seed oil and has previously not been reported to the best of our knowledge.

\section{Anticandidal activity of isolated compound D1}

The isolated compound D1 was tested against C.albicans, C.glabrata, and C. tropicalis is summarized in Table 2 . The purpose of present study was to check the isolated compound D $1(5 \mathrm{mg} / \mathrm{ml})$ against 12 Candida strains obtained from (MTCC) Institute of Microbial Technology, Chandigarh, India, and to evaluate their sensitivity or resistance to currently used antifungal agents. A strong anticandidal activity was observed against C. tropicalis MTCC 230 (20.0 \pm 0.0$)$, C. glabrata MTCC 3814 (16.83 \pm 0.28$)$ and MTCC 3014 (16.66 \pm 0.57$)$, and C. albicans MTCC 1637 (16.0 \pm 0.0$)$. Furthermore, D1 also showed moderate activity against $C$. tropicalis

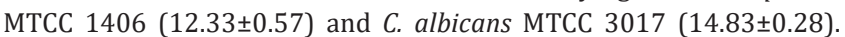
Interestingly C. glabrata MTCC 3981 was found to be resistance against compound and found to be very less effective against Ketoconazole

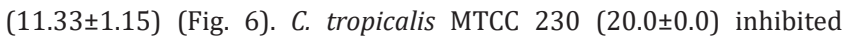
$80 \%$ while compared with standard $(24.0 \pm 0.0)$, followed by another strain of $C$. tropicalis MTCC 1406 (12.33 \pm 0.57$)$, showed less activity compared with strain MTCC $230(20.0 \pm 0.0)$. Ketoconazole $(1 \mathrm{mg} / \mathrm{ml})$ was used as a positive control (Fig. 6). This observation was found to be similar with reported literatures from essential oils of different plants [66-68] and confirmed while comparing with works reported from lemongrass oil inhibits $80 \%$ and found to be most active against human dermatophytic strains and was confirmed by the antifungal activity against $C$. albicans and also from reports by traditional users of lemongrass against ring worm infections $[87,88]$. Several studies have revealed that alkaloids, saponins, tannins, flavonoids, and phenolic compounds possess antimicrobial activities [89]. According to some reports, alkaloids, a class of natural products is complex heterocyclic nitrogenous compounds commonly found to possess antimicrobial properties [90]. Our work proves to be quite interesting due to the presence of alkaloids, flavonoids, and saponins, important classes of bioactive phytochemicals in D. indica seed oil and compound D1. Further, it provides scientific validation for usage of the plant extracts in folk medicine in our region $[49,50]$.

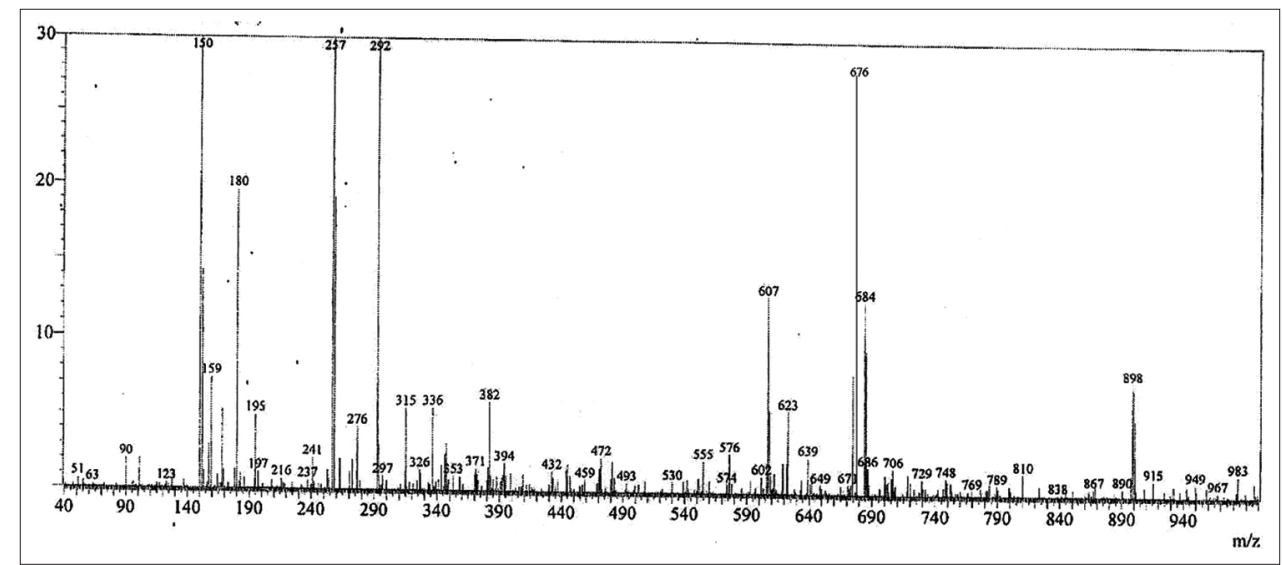

Fig. 4: Mass spectrum of isolated compound from Derris indica seed oil 
The genus Candida includes several species concerned in human pathology such as C. albicans, C. tropicalis, Candida parapsilosis, C. glabrata, Candida krusei, Candida lusitaniae, Candida kefyr, Candida guilliermondii, and Candida dubliniensis [94]. Among this, C. albicans<smiles>COc1ccc(-c2ccc(C3=NN=C(c4ccc(-c5ccc(OC)cc5)c(-c5ccc(OC)cc5)c4)C3(O)O)cc2-c2ccc(OC)cc2)cc1</smiles>

Fig. 5: Structure of 3,5-bis(4,4"-dimethoxy-[1,1':2',1"-terphenyl]4'-yl)-4H-pyrazole-4,4-diol is extremely known to be the most common cause of mucosal yeast infection $[92,93]$. People of all ages are affected by skin infections; the causative agents may be yeast cell C. albicans, mold, and dermatophytes [94]. Importance of fungal infections, the difficulties in their treatment and the increase in resistance to antifungal agents have increased research on therapeutic substitutes. Further in vivo studies were undertaken to elucidate the exact mechanism of action by which compound exerts their antifungal effect

\section{K- Ketoconazole, C- Control, D1- D. indica isolated compound} Excision wound healing from isolated compound D1

The antifungal and therapeutic potential of the isolated compound D1 was evaluated in vivo by using an excision wound healing model on male Wistar rats. No harmful activity was observed for $0.1 \%$ extracts in toxicological test; hence, this concentration was used for further investigation. For in vivo experiment fungal pathogens such as
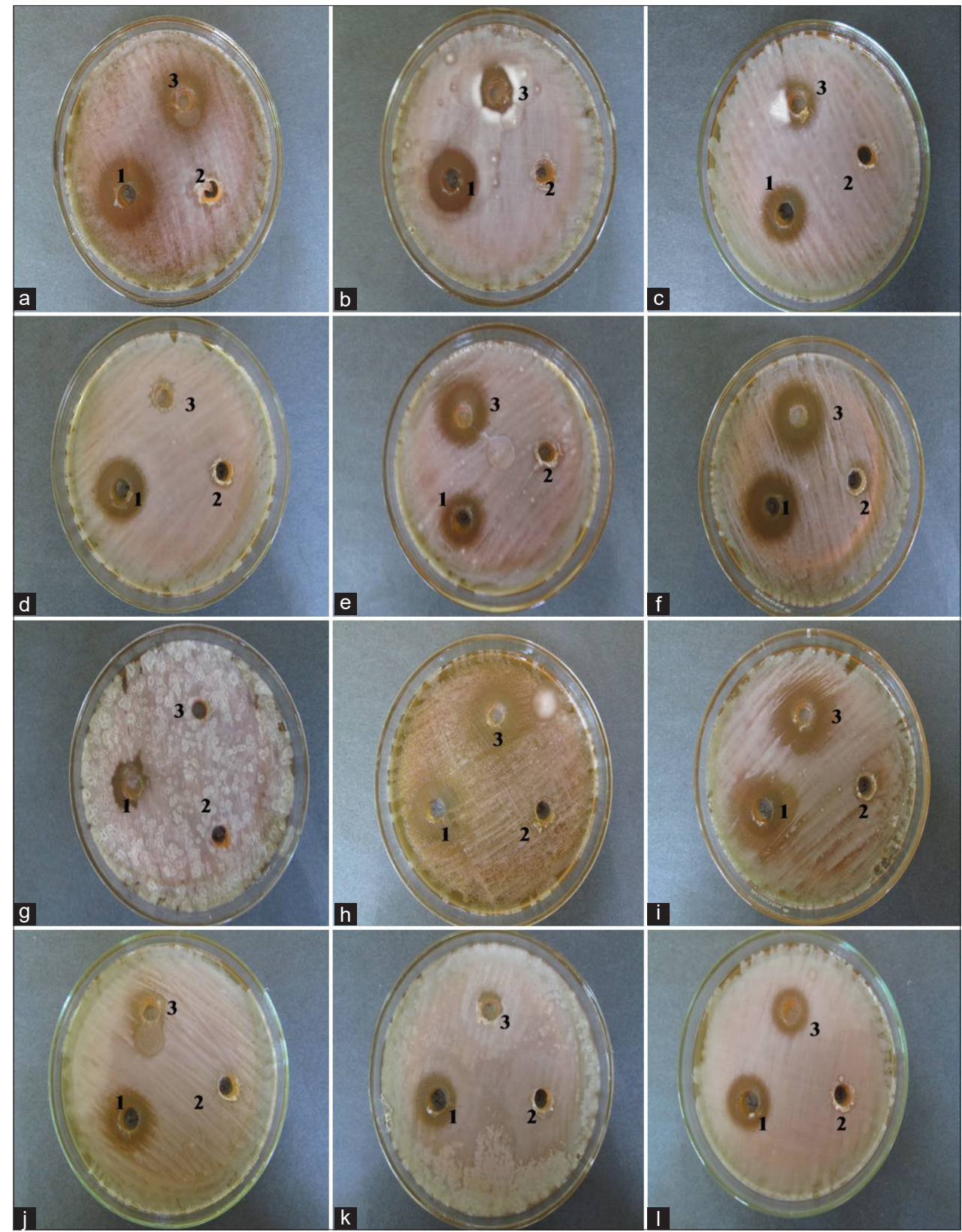

Fig. 6: In vitro susceptibility assay of isolated pure compounds D1 against Candida species. 1. (+ve control $1 \mathrm{mg} / \mathrm{ml}), 2$. (-ve control) and 3. (Isolated compounds D1 $5 \mathrm{mg} / \mathrm{ml}$ ). Candida albicans. a (MTCC 3017), b (MTCC 1637) and c (MTCC 183). Candida tropicalis.d (MTCC 2795), e (MTCC 1406) and f (MTCC 230). Candida gaigantae. g (MTCC 3981), h (MTCC 3841) and i (MTCC 3019). Candida haemulonii. j (MTCC 8303), k (MTCC 1966), and 1 (MTCC 2766) 
T. rubrum, T. tonsurans and $C$. albicans were used. These organisms are mainly responsible for skin diseases common in rodents and also in human beings.

The results of in vivo study are summarized in Table 3 . The treatment was started from the $5^{\text {th }}$ day of the experiment. During the study, it was found that animals induced with fungi $C$. albicans treated with isolated compound was completely cured after 30 days. T. rubrum induced fungi takes 40 days to cure wounds completely. The dermatomycete T. tonsurans which showed similar results while compare with the rats induced by $T$. rubrum. Compound tested for this experiment observed no visual symptoms at the end of the treatment and showed therapeutic activity. Compound showed antifungal activity against C. albicans and T. tonsurans after 30 days and against T. rubrum after 40 days of treatment. The results demonstrated significant wound healing activity of the tested compound as compared to the established drug, ketoconazole. The animals treated with ketoconazole showed $100 \%$ antifungal activity after 10 days of treatment. After this period, the cultures taken from the infected region were inoculated and found negative results. For untreated rats, symptoms were observed at the same time as in treated animals and were present till the end of the experiment. In vivo experiment proved that isolated compound to be most effective against tested pathogens. Alkaloids present in the isolated compound believed to be a responsible constituent to this effect. This assumption was confirmed and reported that sterols, alkaloids, proteins, and carbohydrates show significant wound healing activity [39].

\section{CONCLUSION}

The phytochemical constituents and pharmacological activities proved that the isolated compound was found to be effective against human fungal pathogens and hence can be used as a base molecule in the design of new antifungal drugs.

\section{ACKNOWLEDGMENT}

The authors wish to thank the University Grants Commission, New Delhi, for providing financial assistance through Maulana Azad National fellowship. The authors are also thankful to Dr. Sheikh Rahber, Department of Chemistry, Gulbarga University, Kalaburagi, Karnataka, India, for characterization.

\section{AUTHORS' CONTRIBUTIONS}

Vidyasagar GM designed the experiment and involved in the interpretation of data. Nuzhat Tabassum carried out the experimental work, analysis of data and manuscript preparation. Raghunandan and Shivakumar involved in in vivo activity. Authors went through the final manuscript.

\section{CONFLICT OF INTEREST}

There is no conflict of interest to declare.

\section{AUTHOR'S FUNDIND}

This research received no external fundings.

\section{REFERENCES}

1. Savita S, Rao DV, Sharma RA. A review on Pongamia pinnata (L.) Pierre: A great versatile leguminous plant. Nat Sci 2010;8:130-9.

2. Chopade VV, Tankar AN, Pande VV, Tekade AR, Gowekar NM, Bhandari SR, Khandake SN. Pongamia pinnata: Phytochemical constituents, traditional uses and pharmacological properties: A review. Int J Green Pharm 2008;2:72-5.

3. Pankaj K, Rakesh P. An Phytochemical overview of various parts of Pongamia pinnata (Karanj). World J Pharm Res 2012;2:146-65.

4. Koysomboon S, Altena IV, Kato S, Chantrapromma K. Antimycobacterial flavonoids from Derris indica. Phytochemistry 2006;67:1034-40.

5. Li LY, Li X, Shi C, Deng ZW, Fu HZ, Proksch P, et al. Pongamone A-E, five flavonoids from the stems of a mangrove plant, Pongamia pinnata.
Phytochem 2006;67:1347-52.

6. Yin H, Wu J, Nan H, Zhang S. New prenylated flavones from Pongamia pinnata. Pharmazie 2006;61:76-8.

7. Ahmad G, Yadav PP, Maurya R. Furanoflavonoid glycosides from Pongamia pinnata fruits. Phytochemistry 2004;65:921-4.

8. Yadav PP, Ahmad G, Maurya R. Furanoflavonolds from Pongamia pinnata fruits. Phytochemistry 2004;65:439-43.

9. Carcache-Blanco EJ, Kang YH, Park EJ, Su BN, Kardono LB, Riswan S, et al. Constituents of the stem bark of Pongamia pinnata with the potential to induce quinone reductase. J Nat Prod 2003;66:1197-202.

10. Simin K, Ali Z, Khaliq-Uz-Zaman SM, Ahmad VU. Structure and biological activity of a new rotenoid from Pongamia pinnata. Nat Prod Lett 2002;16:351-7.

11. Chauhan D, Chauhan JS. Flavonoid glycosides from Pongamia pinnata. Pharm Biol 2002;40:171-4

12. Tanaka T, Iinuma M, Yuki K, Fujii Y, Mizuno M. Flavonoids in root bark of Pongamia pinnata. Phytochemistry 1992;31:993-8.

13. Tanaka T, Iinuma M, Yuki K, Fujii Y, Mizuno M. Two new betahydroxychalcones from the root bark of Pongamia pinnata. Chem Pharm Bull 1991;39:1473-5.

14. Kanungo PD, Ganguly A, Guha A, BhattacharyyaA, Adityachaudhury N. Glabone, a new furanoflavone from Pongamia glabra. Phytochemistry 1987;26:3373-4

15. Pathak VP, Saini TR, Khanna RN. Isopongachromene, a chromenoflavone from pongamia glabra seeds. Phytochemistry 1983;22:308-9.

16. Talapatra SK, Mallik AK, Talapatra B. Isopongaglabol and 6-methoxyisopongaglabol, two new hydroxyfuranoflavones from Pongamia glabra. Phytochemistry 1982;21:761-6.

17. Rastogi RP, Mehrotra BN. Compendium of Indian Medicinal Plant. New Delhi, India: Central Drug Research Institute and Publication and Information Directorate; 1993.

18. Talapatra SK, Mallik AK, Talapatra B. Pongaglabol, a new hydroxyfuranoflavone, and aurantiamide acetate, a dipeptide from the flowers of Pongamia glabra. Phytochemistry 1980;19:1199-202.

19. Ujwal P, Pramod KM, Raja NH, Hosetti BB. Antimicrobial activity of different extracts of Pongamia pinnata. Med Aromat Plant Sci Biotechnol 2007;1:285-7.

20. Davies J. Inactivation of antibiotic and the dissemination of resistance genes. Science 1994;264:375-82.

21. Hay RJ. Antifungal drugs used for systemic mycoses. Dermatol Clin 2003;21:577-87.

22. Marques SA, Robles AM, Tortorano AM, Tuculet MA, Negroni R, Mendes RP. Mycoses associated with AIDS in the Third World. Med Mycol 2000;38:269-79.

23. Woodfolk JA, Wheatley LM, Piyasena RV, Benjamin DC, Platts-Mills TA. Trichophyton antigens associated with IgE antibodies and delayed type hypersensitivity. Sequence homology to two families of serine proteinases. J Biol Chem 1998;29:489-96.

24. Harami MA, Abayeh OJ, Ibok NN, Samual EK. Antifungal activity of extracts of some Cassia, Detarium, and Ziziphus species against dermatophytes. Nat Prod Rad 2006;5:357-60.

25. Mandal SM, Barbosa AE, Franco OL. Lipopeptides in microbial infection control: Scope and reality for industry. Biotechnol Adv 2013;31:338-45

26. Kiruba S, Mahesh M, Nisha SR, Miller PZ, Jeeva S. Phytochemical analysis of the flower extracts of Rhododendron arboreum Sm. ssp. nilagiricum (Zenker) Tagg. Asian Pac J Trop Biomed 2011;1:278-80.

27. Rao RR, Tiwari AK, Reddy PP, Babu KS, Ali AZ, Madhusudana K, et al. New furanoflavanoids, intestinal $\alpha$-glucosidase inhibitory and free-radical (DPPH) scavenging, activity from antihyperglycemic root extract of Derris indica (Lam.). Bioorg Med Chem 2009; 17:5170-5.

28. Simin S, Usman GK, Shaiq AM, Viqaruddin A. Chemical constituent from the seeds of Pongamia pinnata (L) Pierre. Pak J Pharm Sci 1996;9:11-20.

29. Naghmana R, Muhammad SA, Muhammad KT, Nurdiyana MY, Bohari MY. Isolation and crystal structure of karanjachromene. Anal Sci 2008;24:21-2.

30. Rangaswami S, Seshadri TR. Pongamol, a New Crystalline Compound from Pongamia Oil. Letters to Editors. Current Science; 1940. p. 179.

31. Suresh KP, Sucheta S, Deepa S, Selvamani P, Latha S. Antioxidant activity in some selected medicinal plants. Afr $J$ Biotechnol 2008;7:1826-8.

32. Seetharam YN, Kotresh K, Uplokar SB. Flora of Gulbarga District. Gulbarga: Gulbarga University; 2000. 
33. Saldanha CJ. Flora of Karnataka. Vol. 1, 2. New Delhi: Oxford and IBH; 1984a.

34. Gamble JS. Flora of Presidency of Madras. Vol. 1, 2, 3. London: Adlord and Son Ltd:; 1935.

35. Gibbs RD. Chemotaxonomy of Flowering Plants. Vol. 11. London: McGill-Queen's University Press; 1974. p. 1236-8

36. Peach K, Tracey MV. Modern Method of Plant Analysis. Vol. 3. New Delhi: Narosa Publishing House; 1959. p. 64.

37. Dey PM, Harborne JB. Methods in Plant Biochemistry. London: Academic Press; 1989. p. 552.

38. Trease GE, Evans WC. Pharmacognsy. $11^{\text {th }} \mathrm{ed}$. London: Brailliar Tiridel Can Macmillian Publishers; 1989.

39. Stahl E. Thin-Layer Chromatography, a Laboratory Handbook. $2^{\text {nd }}$ ed. Berlin, Heidelberg: Springer; 1969.

40. Magaldi S, Mata-Essayag S, de Capriles CH, Perez C, Colella MT, Carolina $\mathrm{O}$, et al. Well diffusion for antifungal susceptibility testing. Int J Infect Dis 2004;8:39-45.

41. Adam K, Sivropoulou A, Kokkini S, Lanaras T, Arsenakis M. Antifungal activities of Origanum vulgare subsp. hirtum, Mentha spicata, Lavanula angustifolia, and Salvia fruticosa essential oils against human pathogenic fungi. J Agri Food Chem 1998;46:1739-45.

42. Marina S, Glamoclija J, Ciric A, Kataranovski D, Marin PD, Vukojevic J, et al. Antifungal activity of the essential oils and components in vitro and in vivo on experimentally induced dermatomycoses at rats. Dig J Nanomater Biostruct 2012;7:959-66.

43. Hutchings A, Scott AH, Lewis G, Cunningham A. Zulu Medicinal Plants: An Inventory. Scottsville, Pietermaritzburg: University of Natal Press; 1996. p. 195-6.

44. Karamanoli K. Secondary metabolites as allelochemicals in plant defence against microorganisms of the phyllosphere. In: Reigosa M, Pedrol N, editors. Allelopathy from Molecules to Ecosystems. United States: Science Publishers Inc.; 2002. p. 277-88.

45. Khan MR, Omoloso AD, Barewai Y. Antimicrobial activity of the Derris elliptica, Derris indica and Derris trifoliata extractives. Fitoterapia 2006;77:327-30.

46. Wagh P, Rai M, Deshmukh SK, Durate MC. Bio-activity of oils of Trigonella foenum-graecum and Pongamia pinnata. Afr J Biotechnol 2007;6:1592-6

47. Baki AM, Khan A, Bari MA, Mosaddik A, Sadik G, Mondal KA. Sub-acute toxicological studies of pongamol isolated from Pongamia pinnata. J Med Med Sci 2007;2:53-7.

48. Vandana M, Sharad V, Megha J, Jaya B, Raka K. Antimicrobial activity of bioactive metabolites isolated from selected medicinal plants. Asian J Exp Sci 2007;21:1-6.

49. Nuzhat T, Vidyasagar GM. Ethnomedicinal oil plants used in treating skin diseases in hyderabad Karnataka Region, Karnataka, India. Int J Chem Tech Res 2017;10:770-84.

50. Nuzhat T, Vidyasagar GM. Phytochemical analysis and antifungal activity of some medicinal oil plants against human pathogens causing skin infections. Int J Chem Tech Res 2017;10:171-7.

51. Suryakant B, Kedarnath, Vishwanath C, Patil CS. Phytochemical screening and characterization of Pongamia pinnata (L) seed oil. Int $\mathrm{J}$ Pharm Anal 2011:3:17-20.

52. Mohamed FR, Khaled MM, Hefnawy TM, Kinni SG, Rajanna LN, Seetharam YN, et al. Chromatographic analysis for fatty acids and lipid soluble bio actives of Derris indica crude seed oil. Chromatographia 2009;70:103-8.

53. Mahmud S, Iqbal Z. Phytochemical investigation of seeds of Pongamia pinnata. Pak J Sci 2009;61:6-9.

54. Khanna RN, Seshadri TR. Chemical components of Pongammia Pinnata: Seeds, flowers and stem bark. Letters to editor. Curr Sci 1964;21:614-45

55. Roy D, Khanna RN. Structure of synthesis of pongol: A new component from the immature seeds of Pongamia glabra. Indian J Chem $1979 ; 18: 525-8$

56. Croteau R, Kutcahn TM, Lewis NG. Natural products. In: B. Buchanan WG, Jones R, editors. Biochemistry and Molecular Biology of Plants. Rockville, MD: American Society of Plant Physiology; 2000. p. 1250-318.

57. Ziegler F. Alkaloid biosynthesis: Metabolism and trafficking. Ann Rev Plant Biol 2008;59:735-69.

58. Haig T. Allelochemicals in plants. In: Zeng RS, Mallik AU, Luo S, editors. Allelopathy in Sustainable Agriculture and Forestry. New York: Springer; 2008. p. 63-104.

59. Soliven FA. The proximate chemical composition of the seed and oil of Philippine oil-bearing seeds: I. Pongamia pinnata Merr. Philipp Agric
$1934 ; 23: 576-87$.

60. Pathak VP, Saini TR, Khanna RN. Chemical constituents of Pongamia pinnata seed. Phytochemistry 1983b;22:308.

61. Roy D, Sharma NN, Khanna RN. Structure and synthesis of iso pongaflavone, a new component of the seeds of Pongamia glabre. Indian J Chem 1977a;15:1138-9.

62. Pathak VP, Saini TR, Khanna RN. Glabrachalcone, a chromenochalcone from Pongamia glabra seeds. Phytochemistry 1983a;22:1303-4.

63. Upadhya GS, Narayanaswami G, Kartha AR. Note on the comparative development of fatty acids in ripening seeds of 16 dicot species producing C16-C18 acid fats. Indian J Agric Sci 1974;44:620-2.

64. Rahul DY, Jain SK, Shashi A, Prajapati SK, Amita V. Pongamia pinnata an overview. Int J Pharm Sci Res 2011;2:496.

65. Evans SV, Fellows LE, Bell EA. Distribution and systematic significance of basic non protein amino acids and amines in the Tephrosieae. Biochem Syst Ecol 1985;13:271-302.

66. Nawrat U, Grzybek-Hryncewicz K, Karpiewska A. Susceptibilty of Candida species to antimycotics determined by microdilution method. Mikol Lek 2000;7:19-26.

67. Conner DE, Beuchat LR. Effects of essential oils from plants on growth of food spoilage yeast. J Food Sci 1984;49:429.

68. Hanafy MS, Hatem ME. Studies on the antimicrobial activity of Nigella sativa seed (black cumin). J Ethnopharm 1991;34:275-8.

69. Aggrawal R, Kharya MD, Srivastava R. Antimicrobial and anthelmintic activities of the essential oil of Nigella sativa Linn. Indian J Exp Biol 1979; $17: 1264-5$.

70. Khan MA, Ashfaq MK, Zuberi HS, Mahmood MS, Gilani AH. The in vivo antifungal activity of the aqueous extract from Nigella sativa seed. Phytother Res 2003;17:183-6.

71. Mashhadian NV, Rakhshandeh H. Antibacterial and antifungal effects of Nigella sativa extracts against $S$. aureus, $P$. aeroginosa and $C$. albicans. Pak J Med Sci 2005;21:47-52.

72. Singh VP, Singh HB, Singh RB. The fungicidal effect of neem extracts on some soil borne pathogens of gram (Cicer arietinum). Mycologia 1980;72:1077-93.

73. Dalleau S, Cateau E, Berges T, Berjeaud J, Limbert C. In vitro activity of essential oils and their major components against Candida albicans yeasts growing planktonically and as biofilms. Int J Antimicrob Agents 2007:29:147.

74. Kishore N, Mishra AK, Chansouria JP. Fungitoxicity of essential oils against dermatophytes. Mycoses 1993;36:211-5.

75. Morris JA, Khettry A, Seitz EW. Antimicrobial activity of aroma chemicals and essential oils. J Am Oil Chem Soc 1979;56:595-603.

76. Ross SA, El-Keltawi NE, Megalla SE. Antimicrobial activity of some Egyptian aromatic plants. Fitoterapia 1980;51:201-5.

77. Yousef RT, Tawil GG. Antimicrobial activity of volatile oils. Pharmazie 1980;35:698-701.

78. Hili P, Evans CS, Veness RG. Antimicrobial action of essential oils: The effect of dimethylsulphoxide on the activity of cinnamon oil. Lett Appl Microbiol 1997;24:269-75.

79. Lis-Balchin M, Deans SG. Bioactivity of selected plant essential oils against Listeria monocytogenes. J Appl Microbiol 1997;82:759-62.

80. Rath CC, Dash SK, Mishra RK. In vitro susceptibility of Japanese mint (Mentha arvensis L.) essential oil against five human pathogens. Indian Perfum 2001;45:57-61.

81. Charchari S, Dahoun A, Bachi F, Benslimani A. In vitro antimicrobial activity of essential oils of Artemisia herba-alba and Artemisia judaica from Algeria. Riv Ital EPPOS 1996;18:3-6.

82. Vijaya M, Cass I, Judy G, Nadeem A, Talpur B, Echard W, et al. Antifungal activities of origanum oil against Candida albicans. Mol Cell Biochem 2001;228:111-7.

83. Nakamura CV, Ishida K, Faccin LC, Filho BP, Cortez DA, Rozental S. In vitro activity of essential oil from Ocimum gratissimum L. against four Candida species. Res Microbiol 2004;155:579-86.

84. Shabnam J, Sobia M, Ibatsam K, Rauf A, Saleem MH. Comparative antimicrobial activity of clove and fennel essential oils against food borne pathogenic fungi and food spoilage bacteria. Afr J Biotechnol 2012;11:16065-70

85. Sunita B, Mahendra R. Antifungal activity of essential oils from Indian medicinal plants against human pathogenic Aspergillus fumigatus and A. niger. World J Med Sci 2008;3:81-8.

86. Ewansiha JU, Garba SA, Mawak JD, Oyewole OA. Antimicrobial activity of Cymbopogon citratus (Lemon Grass) and its phytochemical properties. Front Sci 2012;2:214-20.

87. Fernanda CS, Sara MC, Virginia MS, Deila MS, Botelho NL, Luis RB. Evaluation of antifungal activity of essential oils against potentially 
mycotoxigenic Aspergillus flavus and Aspergillus parasiticus. Braz J Pharm 2012;22:1002-10.

88. Singh G, Sumitra M, Catalan C, Lampasona MP. Chemical, antifungal, antioxidant and sprout suppressant studies on ginger essential oil and its oleoresin. Flavour Fragr J 2005b;20:1-6.

89. Ogunkunle J, Tonia AL. Ethnobotanical and phytochemical studies on some species of Senna in Nigeria. Afr J Biotechnol 2006;5:2020-3.

90. Cowan MM. Plant products as antimicrobial agents. Clin Microbio Rev $1999 ; 12: 564-82$
91. Sulivan DJ, Westerneng TJ, Haynes KA, Bennett DE, Coleman DC. Phenotypic and molecular characterization of a novel species associated with oral candidosis in HIV-infected individuals. Microbiology (Reading) 1995;141:1507-21.

92. Coleman DC, Bennett DE, Sullivan DJ, Gallagher PJ, Henman MC, Shanley DB, et al. Oral Candida in HIV infection and AIDS: New perspectives/new approaches. Crit Rev Microbiol 1993;19:61-82.

93. Sobel JD. Vulvovaginal candidosis. Lancet 2007;369:1961-71.

94. Weitzman I, Summerbell RC. The dermatophytes. Clin Microbiol Rev 1995;8:240-59. 